\title{
Comparison of the nutritive value of naked and husked oat protein with wheat and maize
}

\author{
I. Kosieradzka and M. Fabijańska \\ Department of Animal Nutrition and Feed Science, \\ Warsaw Agricultural University \\ Rakowiecka 26/30, 02-528 Warszawa, Poland
}

\begin{abstract}
The composition and nutritive value of protein of three new lines of Polish naked oat were compared with husked oat, wheat and maize. In all cereals, lysine was the first limiting amino acid but its content was higher in both types of oat than in wheat and maize. The chemical score of naked and husked oat was thus higher than of other cereals; the EAA index of naked oat was the highest.

True digestibility (TD) of naked oat protein was significantly higher than of husked oat and did not differ from TD of wheat and maize. Biological value (BV), and NPU of naked oat protein were significantly higher than of other cereals. PER coefficients determined in a growth experiment were higher in both types of oats than in maize and wheat. Supplementation with lysine increased PER values of all cereals but a significant effect was found only in maize.
\end{abstract}

KEY WORDS: naked oat, biological value of protein, rats

\section{INTRODUCTION}

Breeding naked varieties of oat favourably affected the feeding value of this cereal. The composition and nutrient content of naked oat cultivated in various countries differ considerably (Zarkadas et al., $1995 \mathrm{a}$, b; Nita, 1999). The protein concentration in the grain is an inheritable trait, although it is also significantly affected by environmental conditions. The naked varieties cultivated in America contain up to $18-20 \%$ protein, while Polish varieties have about $14 \%$ and higher protein concentration is a selection criteria in breeding this cereal (Nita, 1999). The nutritional value of the cereal used as a component of diets for monogastric 
animals depends not only on protein content, but also on amino acid composition and nutritional value.

The objective of the study, which is a part of more extensive research on the nutritive value of naked oats cultivated in Poland, was to compare the amino acid composition and nutritional value of naked oats with husked oat and other cercals. The effect of lysine supplementation of diets based on cereal grains was also determined.

\section{MATERIAL AND METHODS}

The grain of 3 tines of naked oat: I - STH 296, II - STH 1407 and III - STH 1451, grown in the experimental station of the Plant Breeding and Acclimatization Institute in Strzelce, two varieties of husked oat: I - German and II - STH 197, wheat var, Jawa, and maize, var. Kosmo, were evaluated in two experiments performed in the Kielanowski Institute of Animal Physiology and Nutrition on growing male rats from the If $z$ Jaz outbred herd. The animals were maintained individually in metabolic cages in a room with $12: 12 \mathrm{~h}$ dark:light program and in a controlled temperature.

Balance experiment: true digestibility (TD), biological value (BV) and net protein utilization (NPU) were determined on 56 rats aged $29 \pm 1$ days with a mean body weight $81 \mathrm{~g}$. The rats were allotted to 7 groups, 8 animals per treatment and fed on diets containing each cereal as the only source of protein at a level corresponding to $9.5 \%$ protein. The level of crude fibre in all diets was equalized to $12.1 \%$ by supplementing with cellulose, while the fat level was adjusted to $5.3 \%$ by supplementation with soya oil. All diets contained a mineral mixture according to NRC (1976) and vitamin mixture according to AOAC (1975). The preliminary period lasted 4 days, the collection of faces and urine, 6 days.

Growth experiment; 84 rats aged $23 \pm 1$ days and mean body weight of $51 \mathrm{~g}$ were allotted to 7 groups, 12 animals per group. Within each group, 6 animals were fed an unsupplemented cereal diet as in the balance experiment and 6 , the same diet supplemented with lysine up to $5.5 \mathrm{~g} / 100 \mathrm{~g}$ protein. Feed intake and weight gain were recorded weekly for three weeks. The protein efficiency ratio (PER), relating body gain to protein intake, was calculated.

The amino acid composition of grain was determined using a Beckman Unichrom Amino Acid Analyzer in samples hydrolyzed with $6 \mathrm{~N} \mathrm{HCl}$; methionine and cystine were determined after oxidation with formic acid. Nitrogen contents in grain, diets, faeces and urine were determined by the Kjeldahl method using a Tecator apparatus. 


\section{RESULTS}

The amino acid composition and nutritional value of protein did not differ among the evaluated varieties within each type of oat, therefore the mean values of three varieties of naked oat and two varieties of husked oat are given in Tables 1,2 and 3.

The amino acid composition of naked and husked oat protein was similar (Table 1). Both oats contained more lysine than wheat and maize, more threonine and methionine than wheat and less than maize. Lysine was the limiting amino acid in

TABLE 1

The content of essential amino acids in cereals, $\mathrm{g} / 16 \mathrm{~g} \mathrm{~N}$

\begin{tabular}{lcccc}
\hline Specification & Naked oat & Husked oat & Wheat & Maize \\
\hline Lys & 4.11 & 3.98 & 2.58 & 2.92 \\
Met & 1.70 & 1.66 & 1.47 & 2.05 \\
Cys & 3.07 & 3.04 & 2.37 & 2.42 \\
Thr & 3.48 & 3.45 & 2.84 & 3.77 \\
Val & 5.51 & 5.12 & 4.34 & 5.07 \\
Arg & 6.85 & 6.86 & 4.91 & 4.99 \\
Ile & 3.74 & 3.68 & 3.50 & 3.66 \\
Leu & 7.39 & 7.34 & 6.83 & 12.81 \\
Phe & 5.16 & 4.97 & 4.57 & 4.85 \\
His & 2.24 & 2.20 & 2.34 & 2.94 \\
Trp & 1.28 & 1.24 & 1.10 & 0.85 \\
Crude protein, \%DM & 15.02 & 10.07 & 15.59 & 9.86 \\
\hline
\end{tabular}

TABLE 2

Nutritional value of protein of naked oat and the compared cereals

\begin{tabular}{lcccccc}
\hline Cereal & $\begin{array}{c}\text { True } \\
\text { digestibility }\end{array}$ & $\begin{array}{c}\text { Biological } \\
\text { value }\end{array}$ & $\begin{array}{c}\text { Net protein } \\
\text { utilization }\end{array}$ & $\begin{array}{c}\text { Chemical } \\
\text { score }\end{array}$ & $\mathrm{CS}_{\mathrm{TD}}^{*}$ & $\begin{array}{c}\text { EAA } \\
- \text { index }\end{array}$ \\
\hline Naked oat & $87.7^{\mathrm{B}}$ & $78.7^{\mathrm{C}}$ & $68.9^{\mathrm{C}}$ & 58.7 & 51.5 & 79 \\
Husked oat & $84.8^{\mathrm{A}}$ & $70.8^{\mathrm{B}}$ & $59.9^{\mathrm{B}}$ & 56.89 & 48.2 & 77 \\
Wheat & $86.1^{\mathrm{AB}}$ & $62.5^{\mathrm{A}}$ & $53.9^{\mathrm{A}}$ & 36.9 & 31.7 & 64 \\
Maize & $86.6^{\mathrm{AB}}$ & $71.8^{\mathrm{B}}$ & $62.2^{\mathrm{B}}$ & 41.7 & 36.1 & 71 \\
ANOVA & $\mathrm{P}=0.0009$ & $\mathrm{P}=0.0000$ & $\mathrm{P}=0.0000$ & - & - & - \\
\hline
\end{tabular}

- coefficient, considering true digestibility of protein $=\mathrm{CS} \times \mathrm{TD}$

means in columns, marked with different letters ${ }^{A . B . C}$ differ statistically for $\mathrm{P}<0.0 \mathrm{l}$ 
TABLE 3

PER value of cereals usupplemented and supplemented with lysine

\begin{tabular}{llc}
\hline Cereal & \multicolumn{1}{c}{ Diet } & PER \\
\hline Naked oat & unsupplemented & $2.60^{\mathrm{CD}} \pm 0.042$ \\
Husked oat & supplemented & $2.50^{\mathrm{D}} \pm 0.800$ \\
& unsupplemented & $2.21^{\mathrm{BC}} \pm 0.550$ \\
Wheat & supplemented & $2.50^{\mathrm{CD}} \pm 0.374$ \\
& unsupplemented & $1.25^{\mathrm{A}} \pm 0.251$ \\
Maize & supplemented & $1.76^{\mathrm{AB}} \pm 0.202$ \\
& unsupplemented & $1.25^{\mathrm{A}} \pm 0.236$ \\
& supplemented & $1.81^{\mathrm{B}} \pm 0.202$ \\
& & \\
\hline
\end{tabular}

means in the columns, marked with different letters ${ }^{A, B, C, D}$ differ statistically for $\mathrm{P}<0.01$

all cereals but the chemical score (CS) of both oats was considerably higher than of wheat and maize, smaller differences were found for the EAA- index, including all essential amino acids (Table 2).

True digestibility (TD) of naked oat protein was greater than of husked oat and did not differ from other cereals. Biological value (BV) and net protein utilization (NPU) were the highest for naked oat and the lowest for wheat. Both indices of protein value were lower in husked than in naked oat.

The PER index determined in the growth experiment was twice as high in naked oat than in maize and wheat and nonsignificantly higher than the PER of husked oat.

Supplementing the diets with lysine increased the PER values of all cereals, but the effect was significant only in maize. However, PER values of lysinesupplemented wheat and maize were still significantly lower than those of supplemented husked and naked oats, which indicates that another limiting amino acid in addition to lysine may lower the protein value of wheat and maize as compared with oat.

\section{DISCUSSION}

Polish naked oat has a similar amino acid profile as that reported by Barneveld et al. (1998), contains more lysine and threonine than Czech varieties (Moudry and Čermak, 1996) and more lysine and threonine but less methionine and cystine than Canadian varieties containing $14.0-14.5 \%$ crude protein (Zarkadas et al., 1995a,b). In the Canadian naked oats, lysine was the first limiting amino acid, similarly as in our work, the second one was threonine. 
Elimination of hulls in oat positively affected protein digestibility. According to Boros et al. (1996) digestibility of protein in rats is decreased mainly by insoluble fibre fractions, but it can also be affected by soluble non-starch polysaccharides such as $\beta$-glucans, and by trypsin and chymotrypsin inhibitors present in oat (Korol et al., 1992).

The quality of cereal protein depends on the content of prolamin-a fraction with the least favourable amino acid composition. Generally, the increase of the total protein content of cereal grain is related to a rise in the prolamin level and deterioration of the quality of this protein. As avenin - prolamin of oat constitutes only $9.4 \%$ (Maurice et al., 1985) to 10\% of protein (Peterson and Brinegar, 1986), the increase in the total protein does not directly deteriorate its quality. Thus, in spite of the high level of protein in the naked oat grain, its feeding value is high.

Robbins et al. (1971) evaluated many varieties of oats and found that an increase of total protein content was not always accompanied by a decrease of lysine concentration in protein as happens in other cereals. The correlation between the level of total protein in oat and the content of methionine and threonine (the second and the third limiting amino acids) was, however, negative.

Genetic improvement of the naked oat towards a higher protein level may increase the deficit of methionine and threonine in the discussed cereal and consequently it may unfavourably affect the biological value of protein.

\section{CONCLUSIONS}

The protein of Polish lines of naked oat has a favourable amino acid composition, good digestibility and high nutritive value. Due to the high content of a goodquality protein, the grain of the naked oat may be a very valuable component of diets for monogastric animals.

\section{REFERENCES}

AOAC, 1975. Association of Official Analytical Chemists, Official Methods of Analysis. $13^{\text {th }}$ Edition. Washington, DC

Barneveld van R J., Szarvas S.R., Barr A.R., 1998. The apparent ileal digestibility of amino acids and digestible energy content of naked oats (Avena sativa cv. Bandicoot) fed to growing pigs. J. Sci. Food Agr. 76, 277-284

Boros D., Rek-Cieply B., Cyran M., 1996. A note on the composition and nutritional value of hullless barley. J. Anim Feed Sci. 5, 417-424

Evaluation of Protein Quality, 1963. National Academy of Science, National Research Council. Washington, DC

Korol W., Jaśkiewicz T., Niściór H., Przegalińska B., Matyka S., 1992. Antitrypsic activity in homegrown cercals (in Polish). Biul, inf. Przcm. Pasz. 31 (1), 47-64 
Maurice D.V., Jones J.E., Hall M.A., Castaldo D.J., Whisenhunt J.E., McConnel J., 1985. Chemical composition and nutritive value of naked oats in broiler diets. Poultry Sci. 64, 529-535

Moudry J., Cermak B., 1996. Comparison of grain yicld and nutritive value of naked and husked oats. Rocz. Akad. Rol. Poznan, Zoot. No. 48, 95-103

Nita Z.T., 1999. Current situation and new directions of oats cultivation in Poland (in Polish). Food 1 (18), Suppl., 186-192

NRC, 1976. Nutrient Requirements of Laboratory Animals. National Academy Press. Washington, DC

Peterson D.M., Brinegar A.C., 1986. Oat Storage Proteins. In: Oats Chemistry and Technology. Webster F.H. AACC St. Paul. 7, 153-303

Robbins G.S., Poneranz Y., Briggle L.W., 1971. Amino acid composition of oat groats. J. Agr. Food Chem. 19, 536-539

Zarkadas C.G., Yu Z., Burrows V.D., 1995a. Assessment of the protein quality of two new Canadiandeveloped oat cultivars by amino acid analysis. J. Agr. Food Chem. 43, 422-428

Zarkadas C.G., Yu Z., Burrows V.D., 1995b. Protein quality of three new Canadian-developed naked oat cultivars using amino acid compositional data. J. Agr. Food Chem. 43, 415-421

\section{STRESZCZENIE}

Porównanie wartości odży wczej bialka owsa nagiego i oplewionego $z$ wartością pszenicy i kukurydzy

Wartość odżywczą białka nowych polskich rodów owsa nagiego ocenioną na podstawic składu aminokwasowego i w testach na szczurach porównano $z$ wartością białka owsa oplewionego, pszenicy i kukurydzy. U wszystkich porównywanych zbóż aminokwasem ograniczającym jest lizyna, ale CS owsa nagiego i oplewionego był wyższy niż pszenicy i kukurydzy. Również wartość indeksu Oscra EAA okazała sį̣ najwyższa dla owsa nagiego. Strawność rzeczywista (TD) białka owsa nagiego była istotnie wyższa niż strawność białka owsa oplewionego i zbliżona do TD pszenicy i kukurydzy. Wartość biologiczna białka owsa nagiego oraz NPU były istotnie wyższe niż pozostałych zbóż. Obliczony na podstawie przyrostów masy ciała zwierząt wskaźnik PER owsa nagiego dwakrotnie przewyższał PER dla pszenicy i kukurydzy, był takize wyższy niż PER owsa z łuską. Dodanie lizyny do diet zbożowych podniosło wartość współczynnika PER, jednak statystycznie istotną poprawę tego wskaźnika otrzymano ty!ko w przypadku kukurydzy. 